\title{
ウォームギヤを用いたスードメカニクス構想と摩擦補償
}

\section{Pseudo Mechanism Scheme and Friction Compensation of a Worm Gear Drive System}

\author{
○正 岩本太郎 （龍谷大） \\ 正(博士） 永野顕法 （龍谷大） \\ 板井雄大（龍谷大） \\ Taro IWAMOTO, Yudai ITAI, Akinori NAGANO \\ Ryukoku University, iwamoto@rins.ryukoku.ac.jp
}

\begin{abstract}
We propose the Pseudo Mechanism scheme. Force feedback control enables back-drive of a worm gear, which naturally cannot be back-driven because of it mechanical stop feature. If the feedback control is switched on or off according to the conditions, its mechanical feature can be shifted from pseudo back-drivable characteristics to natural non-back-drivable characteristics. For example, if the force feedback control is applied only when the force is positive, this system allows the positive rotation and negative rotation is prohibited as a one-way clutch. The compensation method of friction loss of a worm gear is also tested.
\end{abstract}

Key Words: Worm Gear, Force Reflection, Friction Compensation

\section{1.はじめに}

ウォームギヤは一段で二桁程度の減速比が得られる回転伝 達手段として良く使われるが，負荷側からモーターが逆駆動 (バックドライブ)されない特性を持ち, このメカニカルストッ プ機能を生かした使われ方をする。逆に，モータ一駆動を止 めると直ちに停止し，緩停止により慣性力を吸収することが できないため, 用途が限られる問題があった。筆者らは負荷 の回転力により発生するウォームの軸力を力センサで検出し てポジティブフィードバックをかけ，ウォームの軸力が軽減 される方向にモーターを駆動して，ウォームギヤが見かけ上 逆駆動できるようにすることを提案した。この方法は，コン プライアンス特性が重要であるハプティックデバイスやマス タースレイブ・マニピュレータやバランサに適用することに よって，その実現可能性実証してきた[1]-[4].このシステムは 逆駆動特性が制御で実現していることから，電源品失事故な どで制御不能になったときはウォームギヤ本来のメカ二カル ストップ機能が働くため, 負荷による暴走事故を起こさない 本質的安全性を備えている.

ところで，逆駆動特性は制御で実現しているということは， 逆駆動特性を持たせるか持たせないかは意図的に決めること ができることを意味する。すなわち，一方问だけに逆駆動特 性を持たせるとすれば，このシステムはラチェットまたはり ンウェイクラッチとして働く。また, 負荷の回転力が設定值 を超えたら逆駆動特性を持たせるように設定すれば，このシ ステムはトルクリミタとして機能する.このことは, このシ ステムのウォームギヤは擬似的に他の機構要素に取って代わ ることができることを意味している。しかも，これはこのシ ステムが衝いているときはいつでもどの要素にでも切り替え ができ，また方向やトルクの制限值をいつでも变えられるこ とを意味する. そこで，この機能をスードメカニズム(擬似機 構 : Pseudo Mechanism)と称することにする.

このシステムではウォームの軸力を正しく検出することが 重要であるが，ウォームの支持構造に摩擦力が大きく作用す ると正しい顀荷トルクを検出することができず，また歯面の 摩擦力は微小な力の範囲で正確なパワーアシストを阻害する 恐れがある。本論文では，スードメカニズムの提案と実証及 び摩擦の低減策についての検討結果を報告する。

\section{2. 動作原理}

\section{1 撔似的バックドライバビリティ}

ウォームギヤは負荷の力では回転しないというのが一般的 な認識である，逆駆動しないのは，ウオームにかかる回転力 より摩擦力による抵抗のほうが大きいからである。もし，負 荷の力を検出しモーターがこの摩擦抵抗を無くす方向にパワ ーアシストすると, ウォームホイールにかかる負荷トルクに よりウォームが回転し，逆駆動が成立する.

図 1 と図 2 にこのシステムの基本構成を示す. 外力トルク がウォームホイールにかかると，ウォームには軸力が発生す る.この軸力を片持ち梁にひずみゲージを貼った力センサで 計測する.この計測值はサーボ系にポジティブフィードバッ クする. したがって, 外力がかかった方向にモーターが駆動 され摩擦抵抗が打ち消されてウォームが回転する。つまり, 外力トルクはパワーアシストされ, 本来は逆駆動されないウ オームギヤの逆駆動が実現する。なお，図 2 に示す位置のフ イードバックループは位置の復元特性を持たせるためのもの で，逆駆動に関しては本質的には必要ない.

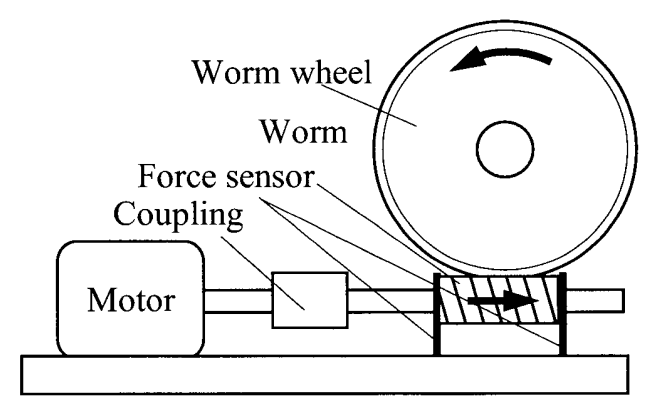

Fig.1 Conceptual figure of work gear drive with force sensor

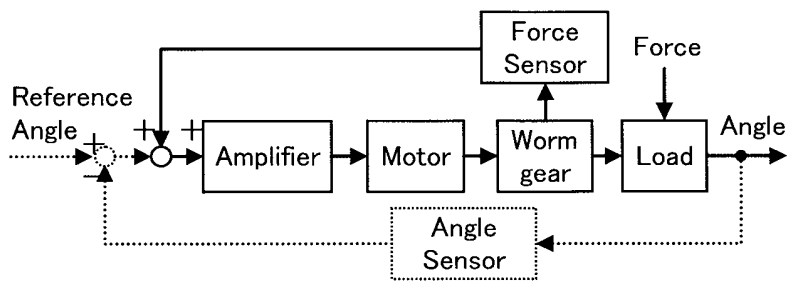

Fig.2 Back drive control system of a worm gear unit 


\section{2 スードメカニズムの原理}

上記の逆駆動システムにおいて，カフィードバックを働か せれば逆駆動が成立する。働かせなければ逆駆動はしない。 したがって，制御を働かせるか働かせないかをスイッチング で選択できる。

図 3 に示すように, カセンサのフィードバック信号ライン に閾値を差し引く要素と, 信号の極性を判定する要素と, そ の結果でフィードバック情報の ON/OFFを切り替えるスイッ チ要素を設ける。

まず，閾値を 0 にして力情報の極性を判定する．力が正の ときにフィードバックループを ON にするようスイッチング を設定すると, 外力トルクが正転方向のときは力フィードバ ック制御が働いてウォームホイールが正方向に回転する.し かし，外力トルクが逆転方向に働くと，力フィードバックル 一プ制御が働かず， ウォームホイールは逆転方向には回転し ない.これはラチェットまたはワンウェイクラッチと同じ動 作である。

次に，閾值を設定すると，外力が閾值を超えた場合にスイ ッチが働いてカフィードバック制御が働き, 逆駆動するよう になる．つまり，これはトルクリミッタと同じ動作である.

さらに, スイッチを一定周期で $\mathrm{ON} / \mathrm{OFF}$ すると摩擦抵抗を 表現できる．PWM 制御と同様に，ONと OFF の時間の割合 (デューティ)を変えることで摩擦抵抗の大きさを変えること ができる。

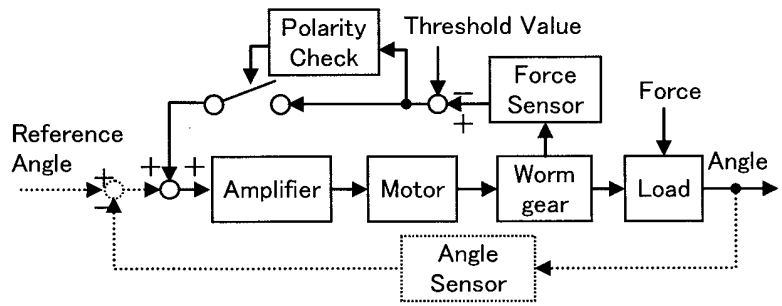

Fig.3 Pseudo mechanism control of a worm gear unit

\section{3 スードメカニスムの利点}

スードメカニズムはカフィードバック制御と逆駆動しない 機構の性質を利用して実現している. 制御系の設定しだいで ウォームギヤがいろいろな機構の性質を持つことになる.こ の設定は機構が動作中でも随時変更が可能であることに大き な特徴がある.

個々の機構の組み合わせで駆動系を構成すれはシステムが 大きくなる．あるいは，運転を停止して機構を取り替えなけ ればならない。これを機構としてはウォームギヤ一つで実現 でき，いつでも機構の特性を他のものに変更できる.また， トルクリミタの許容トルクのように従来は機構の運転を止め て設定していたものを運転中でも随時変更できるように制御 プログラムを作ることができ，リアルタイムでダイナミック な機構特性の操作が可能になる.

\section{3. 実験の方法}

\section{1 ウォーム駆動機構の力検出構造の改良}

前述したように，ウォームの軸力を正確に検出することが このシステムでは大変重要である. 図 4 に力検出機能を備え たウォーム駆動機構を示す．ウォーム軸は軸方向に少し移動 できるように間隔をあけてラジアルベアリングで支えている。 ウォーム軸の動きは平行梁に伝えられ，梁に貼り付けられた ひずみゲージでウォームの軸力を検出する，モーターはべー
スに固定されているので，ウォームの軸方向変位を許容しな がら回転力を伝達しなければならない。このため，オルダム 継ぎ手の角溝の隙間を利用して軸方向変位を許容している.

軸力を正確に計測するためには，軸力に応じてウォームが 軸方向に自由に動かなければならない。図4の構造において は軸を支えるラジアルベアリングと回転軸との閒, 及びオル ダム継ぎ手のスライド部に摩擦抵抗力が発生する。これは力 の正確な計測に悪影響を及ぼす。そこで，機構部を改良する ことにした.

図 5 に改良されたウォーム駆動機構を示す。ウォーム軸の 支持ベアリングは廃止し，ウォーム軸は力検出を兼ねた平行 梁のみで支える．このため，軸受けと軸が摺動するときの摩 擦抵抗は全く無い。また，モーター軸とウォーム回転軸との 接続にオルダム継ぎ手の代わりに図 6 に示すボールカップリ ングを使用した.これは鋼球を用いて軸方向の変位を許容し, 回転トルクを伝達する機構要素である。これにより，ウォー ムの軸方向変位における摩擦抵抗をほぼ無くすことができ, 正確な計測が可能になった。

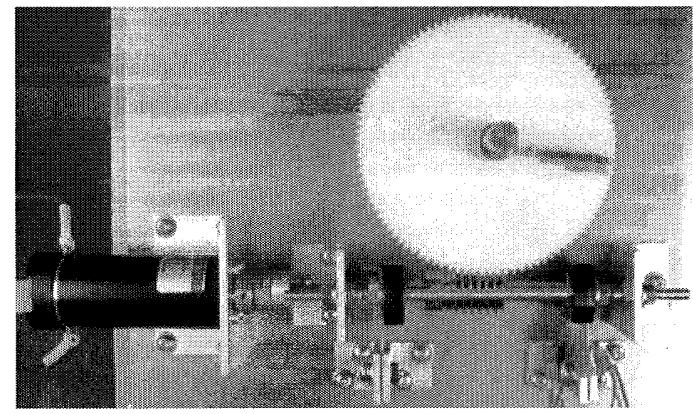

Fig.4 Worm drive system with force sensors

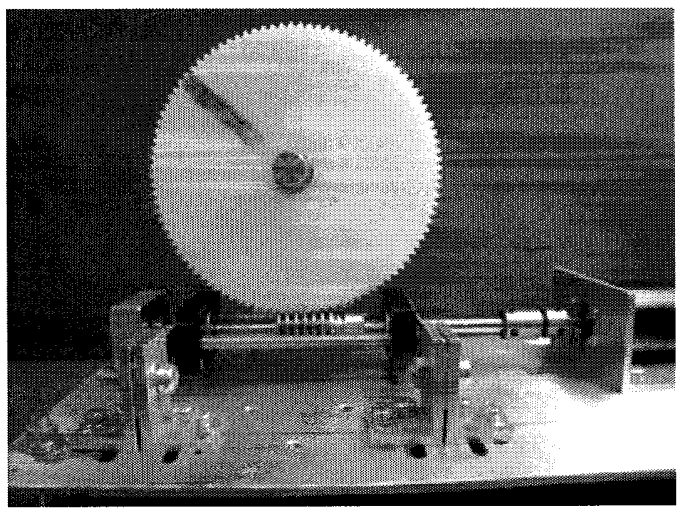

Fig.5 Revised worm drive system with force sensors

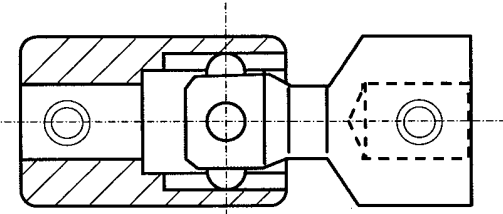

Fig.6 Ball coupling

\section{2 制御システム}

制御システムは図 7 に示すように計算機を使い，ひずみゲ ージで検出した力の情報を $\mathrm{A} / \mathrm{D}$ 変換を介して導入し, エンコ ーダで計測した位置の情報をディジタル信号として入力し, 演算処理した指令值を $\mathrm{D} / \mathrm{A}$ 変換を介してモータドライバーに 入力するシステムである. 閾值の設定, 信号の極性判別と制 御モードの切り替え, 偏差の計算等は $\mathrm{C}$ 言語を用いたプログ 
ラムで処理した．なお，ひずみゲージを利用した力検出はノ イズを拾いやすいため, ディジタルフィルターをかけてノイ ズ除去処理をした.

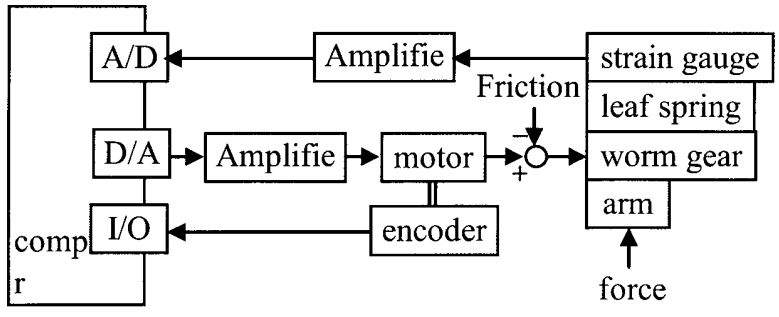

Fig.7 Block diagram of the control system

\section{3 摩摖補償}

よく知られているように，ウォームギヤは摩擦抵抗があり， モーターでパワーアシストするとしても, 摩擦抵抗がモータ 一のトルクによってキャンセルされるまでは動き出さない. つまり，わずかであるが不感帯が存在する．微小なトルクま で正確に表現するには，摩擦補償が必要である。そこで，二 つの方法で摩擦補償を試みた。その一つは図 8 に示す, よく 用いられる PID 制御であり，もう一つは図 9 に示寸摩擦の無 い数学モデルを用いて誤差を補償するモデル追従サーボ制御 である。

実験の結果，図 10 に示すように，モデル追従サーボ制御 の場合は不感帯が減少しているが残留しているのに対し, PID 制御の場合は不感带がほとんど無く, 良い結果が得られた。

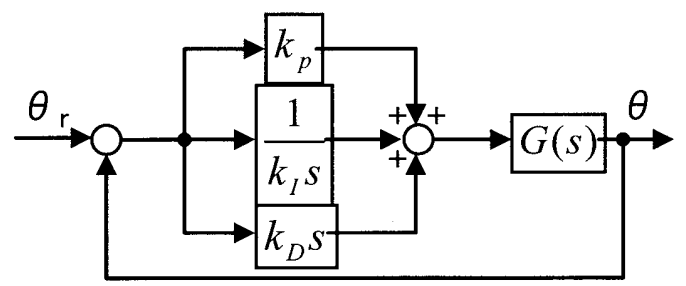

Fig.8 PID control

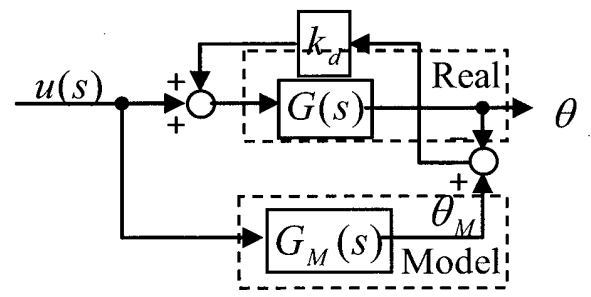

Fig.9 Model follow servo control

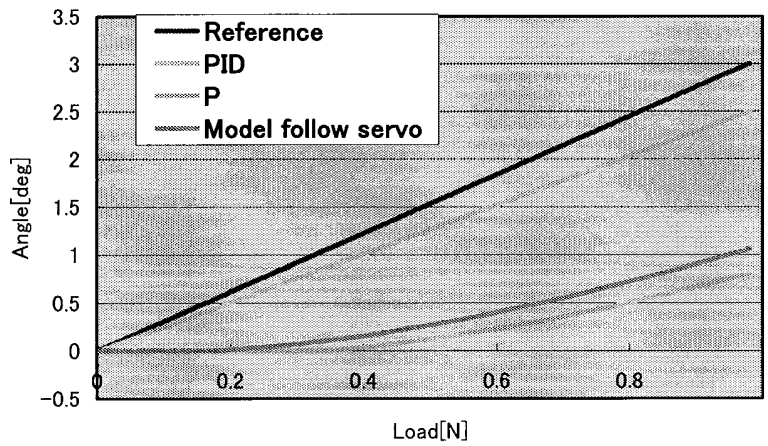

Fig. 10 Experimental Result of friction compensation

\section{4、スードメカニズム確認実験}

\section{1 ワンウェイクラッチ特性の模擬}

ラチェットまたはワンウェイクラッチは負荷の方向，すな わち力検出值の極性によって回転を許容するか拒絶するかを 決める。図 11 に示すように，外力が正方向の場合は外力に よってウォームホイール軸は回転するが，負方向だと回転し ていない.なお，この実験では図 2 に示寸位置のフィードバ ックをはずしていないので，元の位置に復元しているが，復 元機能をはずせばその位置を保持する.図 12 は許容する回 転方向を逆にした場合で，同じように外力が逆方向の場合の み回転を許容していることがわかる。この回転を許容する方 向の切り替えは，制御プログラム中の極性判定を行う部分の 正と負を入れ替えるだけで行うことができる.

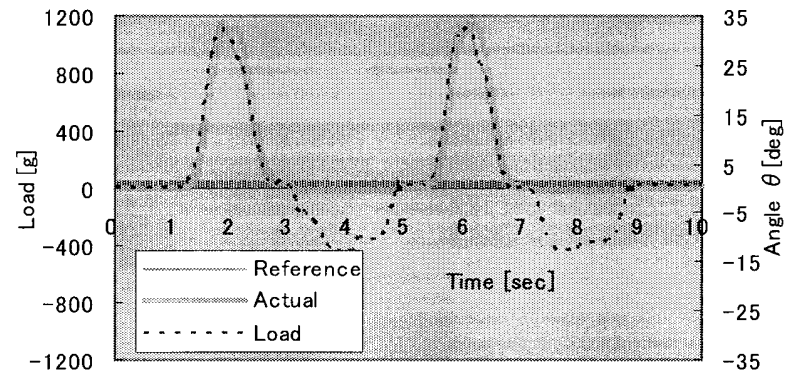

Fig.11 One-way clutch characteristics (Positive)

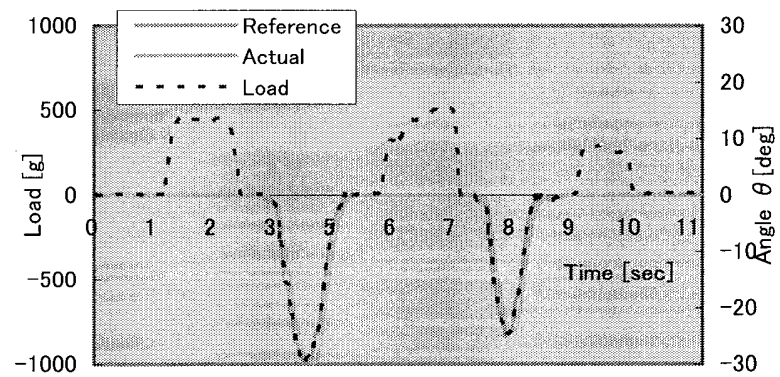

Fig.12 One-way clutch characteristics (Negative)

\section{2 トルクリミタの模㨖}

トルクリミタは負荷アーム先端にかかる外力が制限值 300 $\mathrm{g}$ を超えると 5 度回転を許容するよう設定した。図 13 に示 すように, 外力トルクが許容值の $300 \mathrm{~g}$ を超えるたびに負荷軸 が回転する様子が見て取れる。

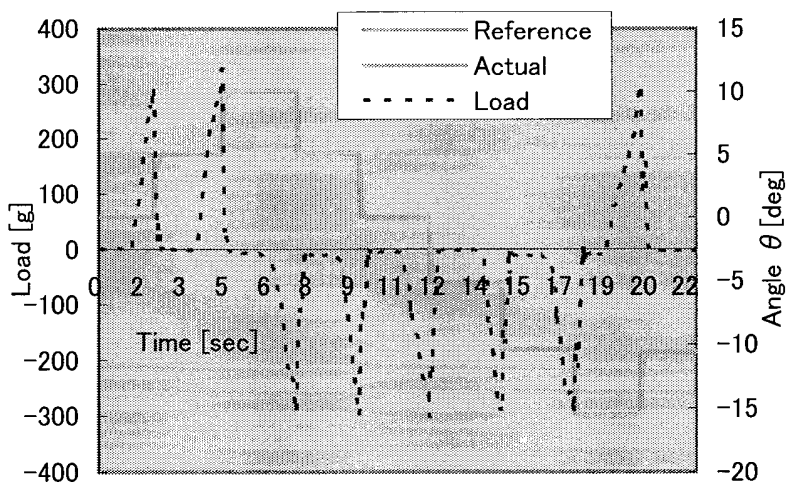

Fig.13 Torque limiter characteristics 


\section{5. まとめ}

負荷の力により逆駆動されないウォームギヤにカフィード バック制御をかけることで逆駆動ができる。この性質を利用 し，条件により制御を ON/OFF することにより，ウェームギ ヤをワンウェイクラッチやトルクリミタとして機能させるこ とができる.これをスードメカニズムすなわち擬似機構とし て提案し，実験によりその可能性を明らかにした。また，ウ オームギヤの弱点である摩擦の補償方法を検討し, PID 制御 により摩擦補償ができることをシミュレーションおよび実験 により示した。

\section{文献}

[1] 渋谷恒司,竹内啓太,寺本智至,岩本太郎,”ウォームギャを用 いた 3 自由度ハプティックデバイスの開発”, 日本ロボット 学会創立 20 周年記念学術講演会, $3 \mathrm{G} 32,2002$.

[2] 岩本太郎,野阪常寛,渋谷恒司,"ウォームギヤを用いた八プ ティックデバイス駆動要素", Robomec2003, 1P1-2F-E5, 2003.

[3] 外間達夫,岩本太郎,橴谷恒司,"ウォームギヤを用いた八プ ティックデバイス駆動要素の摩擦補償",第 21 回日本ロボッ 卜学会学術講演会, 3D13, 2003.

[4] 板井雄大, 岡諭志, 小川真一, 岩本太郎, 渋谷恒司,"ウォ ームギヤを用いたマスタースレイブ・マニピュレータ”, ROBOMEC2006, 1A1-C06, 2006 